\title{
26. DINOFLAGELLATE AGE OF MIDDLE JURASSIC-EARLY CRETACEOUS SEDIMENTS IN THE BLAKE-BAHAMA BASIN 1
}

\author{
Daniel Habib, Queens College of the City University of New York, Flushing, New York \\ and \\ Warren S. Drugg, Chevron Oil Field Research Company, LaHabra, California
}

\begin{abstract}
Biostratigraphic datums of stratigraphically useful dinoflagellates are used to date the Jurassic-Cretaceous sequence in Hole 534A drilled by the Deep Sea Drilling Project. The investigated interval is dated middle Callovian through Vraconian Albian in the 875-m-thick section represented by Cores 534A-127 to 534A-27. Dinoflagellates date the new, lowermost, unnamed lithostratigraphic unit at Hole 534A as middle Callovian through Oxfordian, with basal Kimmeridgian sediments occurring in the approximate position of the boundary with the overlying Cat Gap Formation. The zoned Cretaceous interval in Holes 534A and 391C in the Blake-Bahama Basin ranges from the late Berriasian through the Vraconian.

A zonation is proposed for the stratotype and parastratotype sections of sediments deposited in the European Tethys during the Neocomian (early Berriasian-late Hauterivian). It shows the same chronostratigraphic succession of species common to the Tethys of both North Atlantic and Europe. On the basis of scanning electron micrograph evidence, the epicystal tabulation of Druggidium apicopaucicum Habib is revised.
\end{abstract}

\section{INTRODUCTION}

The dinoflagellate stratigraphy of Hole 534A, drilled by the Deep Sea Drilling Project in the Blake-Bahama Basin, was studied in order to date the palyniferous Mesozoic section. Site 534 is located near the center of the Blake-Bahama Basin, at $28^{\circ} 20.6^{\prime} \mathrm{N}, 75^{\circ} 22.9^{\prime} \mathrm{W}, 22 \mathrm{~km}$ northeast of Hole 391C (Benson, Sheridan et al., 1978) (Fig. 1). Drilling Hole 534A recovered a subseafloor section approximately $1667 \mathrm{~m}$ thick. The palynologically investigated interval is situated in the lower part of the sedimentary section. It is $875 \mathrm{~m}$ thick, and ranges from the stratigraphic level of Core 534A-27 at $764.5 \mathrm{~m}$ subbottom depth to that of Core 534A-127 at $1639.5 \mathrm{~m}$. The lowest part is basalt, from Cores 534A-127 (core catcher sample) to $534 \mathrm{~A}-130$ at $1666.5 \mathrm{~m}$. On the basis of the dinoflagellate evidence, the sedimentary section is dated as middle Callovian near the contact with the underlying basalt (Sample 534A-127-2, 33-35 cm) to Vraconian Albian at the top of the black clay sequence (534A-27-1, 66-68 cm).

The lithostratigraphy is summarized from the comprehensive description given in the Site 534 report (this volume). Habib (this volume) interprets the origin of the particulate organic matter. Examination of the color of palynomorphs suggests that the organic matter near the base of the section is thermally immature.

Four lithostratigraphic units were identified (Fig. 2). In descending stratigraphic order, these are the Hatteras Formation, Blake-Bahama Formation, Cat Gap Formation, and a lowermost, unnamed lithostratigraphic unit that rests directly on the basalt.

\footnotetext{
${ }^{1}$ Sheridan, R. E., Gradstein, F. M., et al., Init. Repts. DSDP, 76: Washington (U.S. Govt. Printing Office).
}

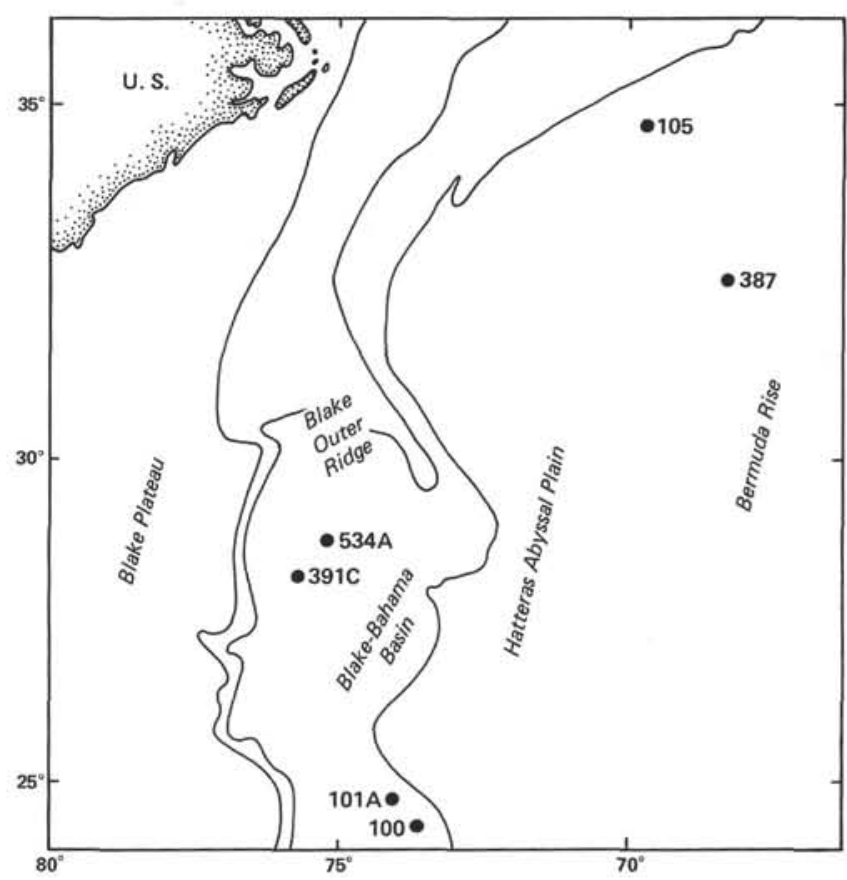

Figure 1. Location of Deep Sea Drilling Project Holes 534A and 391C in the Blake-Bahama Basin and other sites referred to in the text.

The Hatteras Formation is approximately $200 \mathrm{~m}$ thick and spans the interval from Core 534A-27 through Core $534 \mathrm{~A}-48$. Four major lithologies are evident; these consist of an uppermost interbedded black-green noncalcareous clay lithology in Cores 534A-27 to 534A-30; a carbonaceous and lesser interbedded green claystone lithology (534A-31 to 534A-39); yellowish, brownish, and reddish noncalcareous clays (534A-40 to $534 \mathrm{~A}-42)$; and 


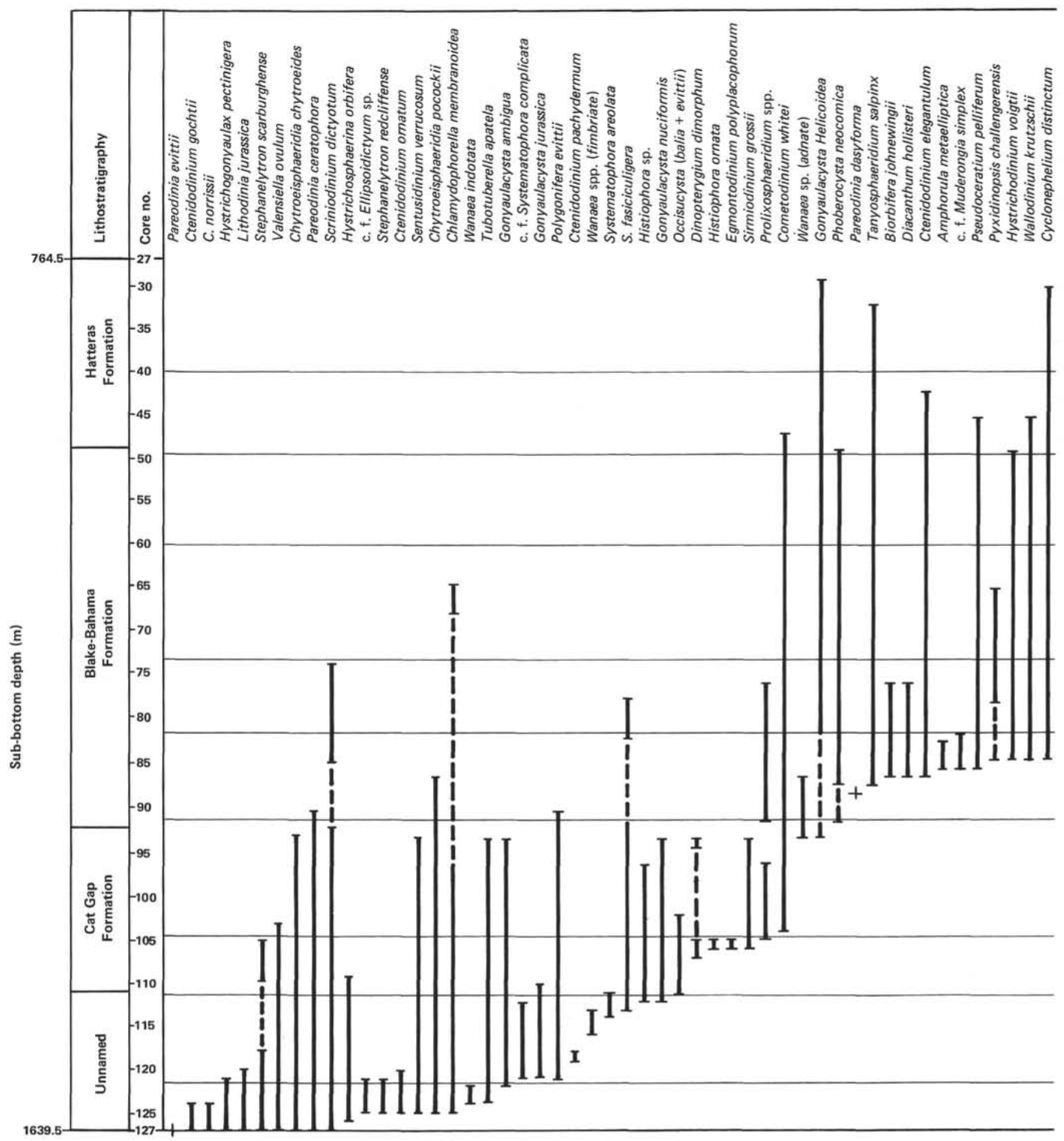

Figure 2. Stratigraphic range chart, showing dinoflagellate zones and ages at Deep Sea Drilling Project Hole 534A. (Major lithostratigraphic units are shown. Asterisks indicate stratigraphic range of angiosperm pollen taxa.)

a lowermost transitional lithology of interbedded carbonaceous clay and calcareous nannofossil claystones (534A-43 to 534A-48). The type locality of the Hatteras Formation is at Site 105 (Fig. 1) in the western North Atlantic. The boundary between the Hatteras Formation and the underlying Blake-Bahama Formation is placed between Cores 534A-48 and 534A-49 in this chapter, based on the uppermost occurrence, in Core 534A-49, of massive, graded bedding in the majority of the calcareous claystones. The last appearance datum of Phoberocysta neocomica (Gocht) in Core 534A-49 correlates the top of the Blake-Bahama Formation with its top in Core 391C-14 from Hole 391C, located $22 \mathrm{~km}$ to the southwest. 


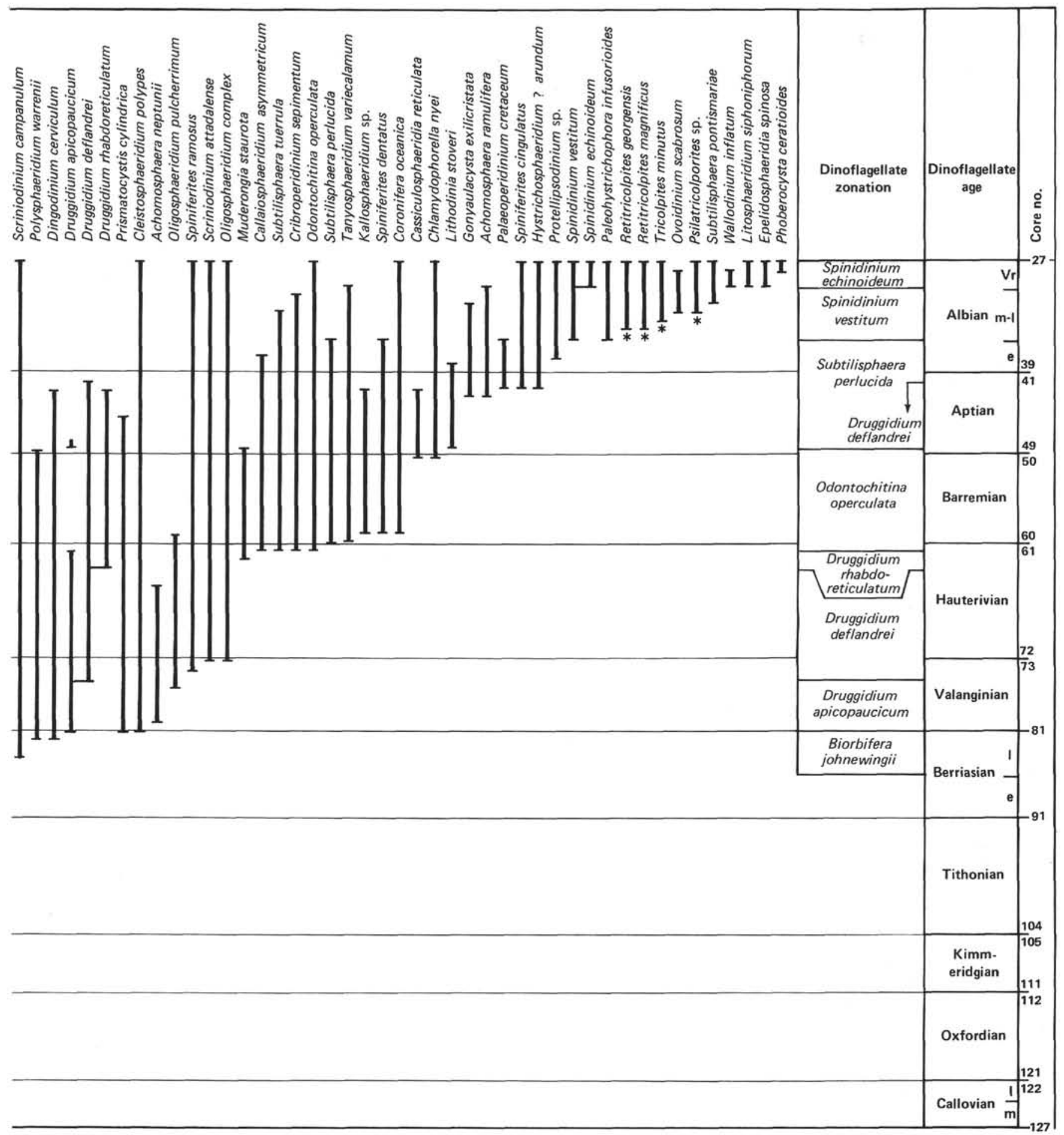

Figure 2. (Continued).

The Blake-Bahama Formation has its type locality at Hole 391C (Jansa, et al., 1979). In Hole 534A, it is 383 $\mathrm{m}$ thick and consists of predominantly calcareous lithologies ranging from the stratigraphic level of Core 534A49 to within Core 534A-92. The upper part comprises limestones with interbedded quartzose and calcareous turbiditic siltstones and sandstones in the stratigraphic interval of Cores 534A-49 to 534A-64. The lower part of the formation, from Cores 534A-65 to 534A-92, consists of finely laminated nannofossil chalks and marls, bioturbated chalks, and minor graded claystones, changing downward to similar but somewhat more heterogeneous lithologies that are distinguished by burrowed limestones rather than chalks. The lowest part of the formation is more uniform, and lacks the laminated character of the lithologies above. It is typically burrowed and 
contains stylolites. Reddish calcilutite laminae occur in Cores 534A-84 and 534A-90.

The Cat Gap Formation occurs in the stratigraphic interval from Core 534A-92 to within Core 534A-111 (Site 534 report, this volume). It is $153 \mathrm{~m}$ thick. Two major lithologies occur. The upper, in Cores 534A-92 to 534A-103, consists primarily of hematitic pale reddish calcareous claystones that darken in color downward. The lower lithology is composed of greenish gray calcareous claystones and darker gray limestone turbidites. Jansa et al., (1979) designated the type locality of the Cat Gap Formation at Site 105 in the western North Atlantic (Fig. 1).

The lowermost lithostratigraphic unit is $140 \mathrm{~m}$ thick and extends from Core 534A-111 to the base of the sedimentary section. It is the oldest unit thus far recovered from the western North Atlantic. The uppermost lithology (Cores 534A-111 to 534A-117) consists of dark variegated claystones that are pale red to blackish red, greenish gray, olive black, and dark gray. The next lower lithology, in Core 534A-117 to the top of Core 534A120 , is distinguished by gray limestones interbedded with variegated claystones. In the interval of Cores 534A120 to $534 \mathrm{~A}-125$, the lithology consists of dark green radiolarian claystones and greenish gray limestones. The lowermost lithology consist of greenish black calcareous nannofossil claystones and reddish brown nannofossil claystones.

\section{DINOFLAGELLATE STRATIGRAPHY}

\section{Distribution of Palynomorphs}

Table 1 lists the 151 samples that were studied. The vast majority of these samples contain stratigraphically useful dinoflagellate cysts, although their relative abundance varies in the various organic facies. Even in the less productive samples, a workable number of species was available from relatively few specimens. Seventeen samples are barren of palynomorphs, or contain specimens that are too poorly preserved for study. These samples were taken from the Oxfordian, Kimmeridgian, and Albian black clay lithologies containing carbonized debris of the micrinitic facies; Tithonian and Berriasian red calcareous clay and calcareous nannofossil ooze lithologies containing the micrinitic or poorly preserved xenomorphic facies; and Aptian red, yellow, or brown noncalcareous clays containing the micrinitic facies (Habib, this volume). The absence or poor preservation of palynomorphs in these samples is attributed to the related effects of sedimentation rate and diagenetic oxygen depletion.

Episodes of rapid supply of terrigenous organic matter (pollen grains, larger fern spores, tracheal tissue, cellular cuticle) admixed with dinoflagellates and amorphous (xenomorphic) debris occur in the middle Callovian and in intervals within Valanginian to early Albian sediments. Kimmeridgian black clay containing appreciable carbonized trachael tissue is considered to represent terrigenous organic matter that was oxidized in the buried sediment environment. Each of these terrigenous events is followed directly by an interval of abundant
Table 1. List of samples, Deep Sea Drilling Project, Hole 534A.

\begin{tabular}{|c|c|c|}
\hline $\begin{array}{c}\text { Sample } \\
\text { (core-section, } \\
\text { interval in } \mathrm{cm} \text { ) }\end{array}$ & $\begin{array}{c}\text { Sample } \\
\text { (core-section, } \\
\text { interval in } \mathrm{cm} \text { ) }\end{array}$ & $\begin{array}{c}\text { Sample } \\
\text { (core-section, } \\
\text { interval in } \mathrm{cm} \text { ) }\end{array}$ \\
\hline $27-1,66-68$ & $58-4,59-61$ & $102-4,68-70$ \\
\hline $27-2,66-68$ & $59-2,30-32$ & $102-5,78-80$ \\
\hline $27-3,66-68$ & $60-3,76-78$ & $103-1,95-96$ \\
\hline $28-2,20-22$ & $61-2,73-75$ & $103, \mathrm{CC}^{\mathrm{a}}$ \\
\hline $29-1,14-16$ & $62-1,41-42$ & $104-2,59-61$ \\
\hline $30-1,15-17$ & $63-2,38-40$ & $104, \mathrm{CC}^{\mathrm{a}}$ \\
\hline $32-1,21-24$ & $64-1,70-72$ & $105-1,17-18$ \\
\hline $33-2,10-12$ & $65-5,40-42$ & $105-1,95-98$ \\
\hline $34-3,22-24$ & $66-5,81-82$ & $105-1,110-111$ \\
\hline $35-1,108-110$ & $67-1,131-133$ & $105-1,126-127$ \\
\hline $36-1,20-22$ & $68-1,39-41$ & $105-2,53-54$ \\
\hline $36-1,59-61$ & $69-1,50-52$ & $105-2,92-94$ \\
\hline $36-1,62-64$ & $70-6,30-32$ & $106-1,3-4$ \\
\hline $36-1,88-90$ & $71-1,29-31$ & $107-2,98-100$ \\
\hline $36-2,88-90^{a}$ & $72-2,34-36$ & $108-1,23-25^{\mathrm{a}}$ \\
\hline $36-3,88-90$ & $73-1,125-127$ & $109, \mathrm{CC}^{\mathrm{a}}$ \\
\hline $37-1,25-27$ & $74-6,54-56$ & $110, \mathrm{CC}^{\mathrm{a}}$ \\
\hline $37-3,25-27$ & $75-1,43-44$ & $111-1,27-29$ \\
\hline $38-5,4-6$ & $76-3,10-12$ & $112-1,69-71$ \\
\hline $39-1,26-38^{a}$ & $77-2,43-45$ & $112-1,108-110$ \\
\hline $39-4,46-48$ & $78-1,104-106$ & $113-1,0-2$ \\
\hline $39-6,0-2$ & $79-2,55-57$ & $114-1,22-24$ \\
\hline $41-1,42-44^{a}$ & $80-2,27-28$ & $115-1,73-74^{a}$ \\
\hline $41-2,42-44^{a}$ & $81-1,61-62$ & $116-1,44-46$ \\
\hline $41-3,42-44^{a}$ & $82-1,53-55$ & $116-1,76-78$ \\
\hline $41-6,42-44$ & $83-4,90-91^{a}$ & $117-1,9-10^{a}$ \\
\hline $42-1,15-17^{a}$ & $84-7,0-2$ & $118-1,5-7$ \\
\hline $42-2,15-17^{a}$ & $85-5,48-49$ & $118-1,100-102$ \\
\hline $42-3,15-17$ & $86-1,148-150$ & $119-1,120-121$ \\
\hline $43-1,92-94$ & $87-6,7-8$ & $120-1,31-33$ \\
\hline $44-3,94-96$ & $88-2,107-108$ & $120-1,43-45$ \\
\hline $45-2,34-36$ & $89-1,81-82$ & $121-1,8-10$ \\
\hline $45-4,78-80$ & $90-1,24-25$ & $121-1,46-48$ \\
\hline $45-5,6-8$ & $90-3,52-53$ & $122-2,68-70$ \\
\hline $46-1,68-70$ & $90-4,30-31$ & $123-1,90-92$ \\
\hline $47-1,66-68$ & $90-5,49-50$ & $123-1,94-94$ \\
\hline $47-4,2-4$ & $90-2,0-1$ & $124-1,8-10$ \\
\hline $48-2,19-21$ & $90-4,30-31$ & $124-1,54-56$ \\
\hline $48-6,19-21$ & $91-1,103-104^{a}$ & $125-1,13-14$ \\
\hline $49-3,30-32$ & $91-2,57-58$ & $125-1,64-66$ \\
\hline $49-4,30-32$ & $91-3,40-41$ & $125-3,144-146$ \\
\hline $49-7,30-32$ & $91-4,107-108$ & $125-3,146-147$ \\
\hline $50-1,50-52$ & $92-2,9-10^{\mathrm{a}}$ & $125-5,88-89$ \\
\hline $50-2,50-52$ & $93-2,99-100$ & $125-6,91-92$ \\
\hline $50-5,50-52$ & $94-4,68-70^{a}$ & $126-2,63-65$ \\
\hline $51-1,30-32$ & $95-4,46-47$ & $126-1,74-77$ \\
\hline $52-3,2-4$ & $96-2,35-36$ & $126-2,23-26$ \\
\hline $53-3,128-130$ & $99-3,79-80$ & $126-3,74-75$ \\
\hline $54-2,41-43$ & $100-2,127-128$ & $126-4,93-95$ \\
\hline $55-3,11-13$ & $101-4,71-73$ & $127-2,33-35$ \\
\hline $56-1,34-36$ & & \\
\hline
\end{tabular}

${ }^{\text {a }}$ Sample is barren of palynomorphs.

xenomorphic debris associated with diversified dinoflagellates and pollen in the genus Classopollis.

Episodes containing relatively few palynomorphs that consist mainly of dinoflagellates occur through most of the Late Jurassic, and within the Hauterivian, Barremian, Aptian, and middle Albian to Vraconian. Pollen grains are very poorly represented in the Late Jurassic and are composed almost entirely of Classopollis, Exesipollenites, and bisaccate grains. These pollen genera are better represented in the Early Cretaceous intervals. 


\section{Biostratigraphic Dating}

Figure 2 shows the dinoflagellate stratigraphy prepared for Hole 534A. The stratigraphy is dated by correlation with the ammonite-zoned dinoflagellate stratigraphy of corresponding European stratotype sections appearing in unpublished reports prepared by W. S. Drugg, and with the summary range chart of ammonitedated dinoflagellates published by Raynaud (1978) for the Jurassic. The Jurassic-Neocomian dinoflagellate stratigraphy at Site 534 (and elsewhere in the western North Atlantic) shows close affinities with the Tethyan province of mediterranean Europe, not only with respect to stratigraphic ranges but also with the relative abundance of certain fossils (e.g., Druggidium, Cometodinium). Bernoulli (1972) showed a comparable relationship between the facies of the western North Atlantic and the European Tethys. Accordingly, the Tethyan definition of the Kimmeridgian Stage is used, where the Kimmeridgian/Tithonian boundary is placed at the base of the Gravesia elegans ammonite zone.

The interval from middle Callovian (Core 534A-127) through early Berriasian (Core 534A-87) is dated on the basis of the first appearance (FAD) and last appearance (LAD) datums of stratigraphically useful dinoflagellates. Study of additional sections of corresponding age in the North Atlantic may show that these fossils are useful for defining biostratigraphic zones. The late Berriasian (Core 534A-86) through Vraconian (534A-27) interval is dated on the basis of the North Atlantic zonation published by Habib (1977). The same zonal sequence occurring at other sites in the western North Atlantic is present at Site 534, except that the uppermost (early Cenomanian) part of the Spinidinium echinoideum Zone and the entire middle to late Cenomanian Trithyrodinium suspectum Zone were not found. The zonation of Hole 534A correlates precisely with that of Hole 391C (Habib, 1978). At both sites in the Blake-Bahama Basin, the zonation ranges from late Berriasian to Vraconian.

All the zonal species in the Cretaceous zonation are illustrated by Habib $(1976 ; 1978)$ and by Sverdlove and Habib (1974). The Deflandrea vestita and Deflandrea echinoidea Zones are renamed the Spinidinium vestitum and Spinidinium echinoideum zones, respectively. The Odontochitina operculata Zone of Habib (1977) is abandoned; its Phoberocysta neocomica Subzone is elevated to the rank of zone and renamed the Odontochitina operculata Zone, and its Subtilisphaera perlucida Subzone is also elevated to the rank of zone. In none of these changes of name or zonal rank has the definition of the original zones and subzones been modified.

A zonation is proposed for the Tethyan stratotype sections of the Neocomian (early Berriasian-late Hauterivian) stages and is compared with the North Atlantic Neocomian zonation.

\section{Jurassic-Berriasian (middle Callovian-early Berriasian)}

\section{Callovian}

The interval ranging from Samples 534A-127-2, 33$35 \mathrm{~cm}$ through $534 \mathrm{~A}-122-2,68-70 \mathrm{~cm}$ is dated middle
Callovian to late Callovian. Stephanelytron scarburghense Sarjeant, emended Stover, Sarjeant, and Drugg is present in the former sample, which indicates that this sample is not older than middle Callovian. Stover et al. (1977) indicated that this species ranges from middle Callovian to Kimmeridgian, based on its stratigraphy in European ammonite-dated sections. The last appearance of Wanaea indotata Drugg in the uppermost sample of this interval indicates an age not younger than late Callovian. Other stratigraphically useful species occurring in this interval are Scriniodinium dictyotum Cookson and Eisenack, Stephanelytron redcliffense Sarjeant, emended Stover, Sarjeant, and Drugg, Pareodinia evittii (Pocock), Hystrichogonyaulax pectinigera (Gocht), Lithodinia jurassica Eisenack, Ctenidodinium ornatum (Eisenack), C. gochtii (Sarjeant) and C. norrisii (Pocock). The occurrence of Scriniodinium dictyotum and Stephanelytron redcliffense supports an age assignment not older than Callovian. $P$. evittii was observed in the lowermost sample only. C. gochtii and a closely related species that is characterized by intratabular ridges within septal plate boundaries (Pocock, 1972), C. norrisii, last appear in Sample 534A-124-1, 54-56 cm, which suggests that this stratigraphic level is not younger than middle Callovian. Gonyaulacysta jurassica (Deflandre) first appears in the uppermost sample (534A-122-2, 68$70 \mathrm{~cm}$ ). In the European sections, this species ranges down through the Callovian.

The schizaeaceous fern spore Cicatricosisporites is represented by several species in the interval dated middle Callovian. This occurrence is unusual, as the earliest appearance of this genus has been used to date sediments in the Late Jurassic. However, it has been reported from the Callovian of North Africa by Reyre (1973), and Dörhöfer (1979) has suggested that it migrated to higher latitudes during the Late Jurassic. The occurrence of these spores in appreciable amounts in deep-sea sediments is related to rapidly deposited terrigenous organic matter (Habib, 1978) and to proximity to a shoreline in the neritic facies.

\section{Oxfordian}

The interval from Sample 534A-121-1, 46-48 cm through Sample 534A-112-1, 69-71 cm is dated Oxfordian. Polygonifera evittii Habib (1972) (=? Senoniasphaera frisia Raynaud, 1978) first appears in the lowermost sample. In the European sections, this species ranges from earliest Oxfordian into the Berriasian. In Hole 534A, the stratigraphic ranges of $P$. evittii and Wanaea indotata do not overlap. This places the Callovian/Oxfordian boundary between Samples 534A-122-2, 68-70 $\mathrm{cm}$ and 534A-121-1, 46-48 cm. The interval from Cores 534A-121 through 534A-120 lies within the early Oxfordian. Hystrichogonyaulax pectinigera and Lithodinia jurassica last appear in Cores 534A-121 and 534A120 , respectively, which supports the basal Oxfordian age of this interval. In Hole 534A, Stephanelytron redcliffense last appears in the early Oxfordian, in Sample 534A-121-1, 8-10 cm. Systematophora sp. cf. S. complicata Neale and Sarjeant is restricted to the Oxfordian in Hole 534A. Systematophora areolata Klement first 
appears in Sample 534A-114-1, 22-24 cm, which indicates that this level is not older than middle Oxfordian.

\section{Kimmeridgian}

The interval from Samples 534A-111-1, 27-29 cm through $534 \mathrm{~A}-105-1,17-18 \mathrm{~cm}$ is dated Kimmeridgian. The Oxfordian/Kimmeridgian boundary is placed between Samples 534A-112-1, 69-71 cm and 534A-111-1, $27-29 \mathrm{~cm}$, based on the first appearance of Occisucysta balia Gitmez in the latter sample. $O$. balia first appears in sediments of the earliest Kimmeridgian in the ammonite-dated stratigraphy in Europe. Gonyaulacysta nuciformis (Deflandre) first appears in the approximate position of this boundary, in Sample 534A-112-1, 69-71 $\mathrm{cm}$. According to Raynaud (1978), G. nuciformis first appears very close to the Oxfordian/Kimmeridgian boundary in the stratotype sections. $G$. jurassica has its last stratigraphically persistent appearance in Sample 534A-110,CC.

Samples from Cores 108 and 109 are either barren of palynomorphs in oxidized black clay (Habib, this volume) or contain few dinoflagellates. Dinopterygium dimorphum (Ioannides, Stavrinos, and Downie) Drugg occurs in Sample 534A-107-2, 98-100 cm and ranges discontinuously to near the top of the Jurassic, in Sample 534A-93-2, 99-100 cm. This species becomes stratigraphically persistent in the Kimmeridgian-Tithonian. Histiophora ornata Klement, a species that was described by Klement (1960) from the Kimmeridgian of Germany, occurs in Samples 534A-106-1, 3-4 cm and 534A-105-2, 92-94 cm. Egmontodinium polyplacophorum Gitmez and Sarjeant first appears in Sample 534A$106-1,3-4 \mathrm{~cm}$ as well, which is indicative of the Kimmeridgian to Tithonian. Stephanelytron scarburghense last appears in Sample 534A-105-2, 92-94 cm, which indicates an age not younger than Kimmeridgian (Stover, et al., 1977).

Another dinoflagellate that is valuable for dating sediments not older than Kimmeridgian in the North Atlantic sections is the morphotype with a pentagonal outline, attached operculum, and perforate antapical pericyst assigned to Sirmiodinium grossii Alberti. S. grossii was described from the Early Cretaceous, and is known to range into the Callovian in the European sections. However, in the Callovian and Oxfordian, trilobate forms occur together with the pentagonal, a phenomenon that was found in Greenland (Fensome, 1979), Alaska, and in the European stratotype sections. In Hole $534 \mathrm{~A}$, and at Sites 100 and 105, the pentagonal morphotype is morphologically close to Senoniasphaera jurassica Gitmez and Sarjeant, from which it is distinguished by its perforate pericyst. In the North Atlantic, Sirmiodinium grossii (pentagonal) is restricted to the Kimmeridgian-Tithonian. It has not been found in Cretaceous North Atlantic sediments thus far.

\section{Tithonian}

The Tithonian is identified in the interval from Samples 534A-104-2, 59-61 cm through 534A-91-3, 40-41 $\mathrm{cm}$. The Kimmeridgian/Tithonian boundary is placed between Samples 534A-105-1, 17-18 cm and 534A-104-2,
59-61 cm, based on the first appearance of Cometodinium whitei (Deflandre and Courteville) in the latter sample. Support for the position of this boundary is drawn from the last appearance of Stephanelytron scarburghense in Sample 534A-105-2, 92-94 cm. C. whitei is an Early Cretaceous species that is known to occur in the Tithonian of France. It also occurs in the Late Jurassic at Site 105 (Habib, 1976), Hole 99A, and Site 100 in the western North Atlantic. It is a valuable guide species in the North Atlantic stratigraphy, because it is one of the few dinoflagellate fossils that are stratigraphically persistent through the poorly palyniferous interval across the Jurassic/Cretaceous boundary. This species has not been observed in any Kimmeridgian or older sample in the stratotype sections of England and France.

A number of species do not range younger than Tithonian at Hole 534A. These include Dinopterygium dimorphum, Chytroeisphaeridia chytroeides (Sarjeant), Sentusidinium verrucosum (Sarjeant), Tubotuberella apatela (Cookson and Eisenack), Gonyaulacysta ambiguua (Deflandre), G. nuciformis, and Sirmiodinium grossii (pentagonal). The Cretaceous species Gonyaulacysta helicoidea (Eisenack and Cookson) first appears in Sample 534A-93-2, 99-101 cm, but does not become stratigraphically persistent until Sample 534A-81-1, 61-62 cm.

\section{Early Berriasian}

The early Berriasian is identified in the interval from Samples 534A-91-2, 57-58 cm through 534A-87-6, 7-8 $\mathrm{cm}$. This interval, and that ranging down to the base of the Blake-Bahama Formation across the Jurassic/Cretaceous boundary, is poorly palyniferous and contains only few stratigraphically persistent dinoflagellates. The earliest Berriasian, in the lowermost sample, 534A-91-2, $57-58 \mathrm{~cm}$, is distinguished by the first stratigraphically persistent appearance of Prolixosphaeridium sp. cf. $P$. granulosum, which becomes stratigraphically persistent in the stratotype stages of the Neocomian, and in the Neocomian in Hole 534A. It is morphologically close to, and possibly conspecific with, Prolixosphaeridium granulosum, which occurs in sediments of the Late Jurassic in Hole 534A. Other species are rare and scattered in the early Berriasian in Hole 534A and do not become stratigraphically persistent until the approximate position of the lower boundary of the Biorbifera johnewingii Zone. These include Phoberocysta neocomica (Gocht) and Tanyosphaeridium salpinx Norvick. Pareodinia dasyforma Wiggins was observed in one sample (534A-88-2, 107-108 cm).

\section{Cretaceous Zonation}

\section{Biorbifera johnewingii Zone (Habib, 1977)}

Of the late Berriasian, this zone is based on the first appearance datum of Biorbifera johnewingii Habib in Sample 534A-86-1, 148-150 cm and extends up to Sample $534 \mathrm{~A}-82-1,53-55 \mathrm{~cm}$, directly below the first appearance of Druggidium apicopaucicum Habib. Other species that first appear in Hole 534A include Diacanthum hollisteri Habib, Ctenidodinium elegantulum Millioud, Pseudoceratium pelliferum Gocht, Hystrichodin- 
ium voigtii (Alberti), Wallodinium krutzschii (Alberti), Cyclonephelium distinctum Deflandre and Cookson, and Dingodinium cerviculum Cookson and Eisenack. Several of these species, for example, Diacanthum hollisteri and C. elegantulum, first appear earlier in the late early Berriasian in the Berrias stratotype section. Amphorula metaelliptica Dodekova is restricted to this zone in the western North Atlantic and in the Berrias section.

\section{Druggidium apicopaucicum Zone (Habib, 1977)}

This zone is distinguished by the first appearance of D. apicopaucicum in Sample 534A-81-1, 61-62 up to Sample 534A-76-3, 10-12 cm, directly below the phylogenetic appearance (PAD) of Druggidium deflandrei (Millioud). The age of the zone is Valanginian; the lower boundary is earliest Valanginian, in the approximate position of the Berriasian/Valanginian boundary, based on correlation with the stratotype stratigraphy. Prismatocystis cylindrica Habib and Cleistosphaeridium polypes (Cookson and Eisenack) first appear in this zone in Hole 534A. The Jurassic species Systematophora fasciculigera last appears within this zone.

\section{Druggidium deflandrei Zone (Habib, 1977)}

This zone is based on the phylogenetic appearance of D. deflandrei in Sample 534A-75-1, 43-44 cm up to Sample 534A-64-1, 70-72 cm, immediately below the phylogenetic appearance of Druggidium rhabdoreticulatum Habib. The zone ranges from late Valanginian to Hauterivian. Scriniodinium dictyotum last appears in the late Valanginian of the stratotype sections, which suggests that the Valanginian/Hauterivian boundary lies immediately above the last appearance of this species in Sample 534A-73-1, 125-127 cm. Biorbifera johnewingii and Diacanthum hollisteri last appear in Sample 534A$75-1,43-44 \mathrm{~cm}$, which supports dating the lower boundary late Valanginian.

\section{Druggidium rhabdoreticulatum Zone (Habib, 1977)}

This zone is identified on the basis of the phylogenetic appearance of D. rhabdoreticulatum in Sample 534A$63-2,38-40 \mathrm{~cm}$ up to Sample 534A-62-1, $41-42 \mathrm{~cm}$, immediately below the first appearance of Odontochitina operculata (Wetzel). This zone is thin in the western North Atlantic but is geographically widespread. It was not found in the Neocomian stratotype sections. By its stratigraphic position between the Druggidium deflandrei and Odontochitina operculata zones, this zone is assigned to the Hauterivian.

\section{Odontochitina operculata Zone (new name proposed for Phoberocysta neocomica Subzone defined by Habib, 1978)}

The Phoberocysta neocomica Subzone is elevated to the status of Zone and is renamed the Odontochitina operculata Zone. Its definition remains the same (Habib, 1978 , p. 891). However, it is restricted relative to the definition of the original Odontochitina operculata Zone of Habib (1977), which is abandoned.

The interval of this zone is recognized from the first appearance of $O$. operculata in Sample 534A-61-2, 73-75 $\mathrm{cm}$ to the last appearance of Phoberocysta neocomica (Gocht) in Sample 534A-49-4, 30-32 cm. The zone is of the late Hauterivian to the early Bedoulian (early early Aptian). DeRenéville and Raynaud (1981) used these two species to identify the Barremian in its stratotype section. Although the greater thickness of this zone in Hole 534A is of the Barremian, O. operculata is known to first appear in the late Hauterivian Subsaynella sayni ammonite zone, and $P$. neocomica occurs in the lower part of the Bedoulian (early Aptian) in the La Bédoule stratotype. Also, Millioud (1969) reported P. neocomica in the lower part of the Aptian in the Barremian stratotype section at Angles.

Subtilisphaera terrula (Davey), S. perlucida (Alberti), Cribroperidinium sepimentum Neale and Sarjeant, Spiniferites? dentatus (Gocht), Coronifera oceanica Cookson and Eisenack, and a smooth spherical adnate species in Kallosphaeridium sp. first appear near the lower boundary. Druggidium apicopaucicum has its last stratigraphically persistent appearance in Sample 534A-61-2, $73-75 \mathrm{~cm}$. This species last appears in the late Hauterivian at other sites in the North Atlantic (Habib, 1977, p. 351; fig. 2) and in the stratotype sections; however, three specimens were observed in Sample 534A-49-7, 30$32 \mathrm{~cm}$. Because of the large gap represented by the interval from Cores $534 \mathrm{~A}-61$ to $534 \mathrm{~A}-49$, the occurrence of this species in Core 534A-49 is anomalous and is considered to be due to reworking. Chlamydophorella nyei Cookson and Eisenack first appears near the upper boundary of the Odontochitina operculata Zone.

\section{Subtilisphaera perlucida Zone (Habib, 1978)}

This zone was originally described as a subzone (Habib, 1978); it is elevated to the status of zone. In Hole $534 \mathrm{~A}$, it is represented by the interval from Sample 534A49-3, 30-32 cm, immediately above the last appearance of Phoberocysta neocomica, to Sample 534A-36-3, 88-90 $\mathrm{cm}$. Named after $S$. perlucida, which ranges from below and through it, the zone ranges in age from Aptian to early Albian. The Aptian/Albian boundary is placed within the zone immediately above the last appearance of Druggidium deflandrei in Sample 534A-41-6, 42-44 $\mathrm{cm}$. Species that first appear in the lower part (Aptian) include Cassiculosphaeridia reticulata Davey and $\mathrm{Hy}$ strichosphaeridium? arundum Eisenack and Cookson.

Samples from Core 534A-39 contain numerous specimens of the long-ranging species Cyclonephelium distinctum Deflandre and Cookson. Included in this species is a tabulated morphotype that resembles Cyclonephelium tabulatum Davey and Verdier.

Spinidinium vestitum Zone (new name for Deflandrea vestita Zone of Habib, 1977)

This zone is represented by the first appearance of Spinidinium vestitum Brideaux (e.g., Sverdlove and Habib, 1974, plate 1, figs. 7-12) in Sample 534A-36-1, 88$90 \mathrm{~cm}$, up to Sample $534 \mathrm{~A}-32-1,21-24 \mathrm{~cm}$. Its age is middle Albian (or late early Albian) to late Albian.

The Spinidinium vestitum Zone contains the oldest tricolpate angiosperm pollen taxa recovered in the western North Atlantic. In Hole 534A, Retitricolpites geor- 
gensis Brenner, $R$. magnificus Habib, $R$. sphaeroides Pierce, and Tricolpites minutus (Brenner) first appear near the base of this zone. Psilatricolporites sp. (Habib, 1978, plate 1, fig. 8) first appears in the upper part.

The dinoflagellate species Palaeohystrichophora infusorioides Deflandre first appears near the base of this zone. Subtilisphaera pontismariae (Deflandre) first appears very near the top (Sample 534A-32-1, 32-34 cm). $S$. terrula and S. perlucida last appear within the Spinidinium vestitum Zone.

Spinidinium echinoideum Zone (new name for Deflandrea echinoidea Zone of Habib, 1977)

This zone is represented by the phylogenetic appearance of Spinidinium echinoideum (Cookson and Eisenack) Lentin and Williams, 1976. S. echinoideum (e.g., Sverdlove and Habib, 1974, plate 1, figs. 1-6) first appears in Sample 534A-30-1, 15-17 cm and ranges to the top of the investigated section in Sample 534A-27-1, $66-68 \mathrm{~cm}$.

In the North Atlantic, the Spinidinium echinoideum Zone ranges from Vraconian Albian to early Cenomanian. In the Blake-Bahama Basin (Holes 534A and 391C), however, the top of the zone was not observed. Its age in this area is considered to lie completely within the Vraconian on the basis of the occurrence of two species in the uppermost sample that terminate in the Vraconian, S. vestitum and Hystrichosphaeridium? arundum. At Holes 101A and 105, S. vestitum and H.? arundum last appear in sediments dated by planktonic foraminifers (Luterbacher, 1972) as Vraconian Albian.

Litosphaeridium siphoniphorum (Cookson and Eisenack), Epelidosphaeridia spinosa (Cookson and Hughes), and Wallodinium inflatum Habib first appear at or near the base of the Spinidinium echinoideum Zone.

\section{NEOCOMIAN STRATOTYPE ZONATION}

Figure 3 depicts the stratigraphy and zonation of selected dinoflagellate taxa in Tethyan ammonite-dated Neocomian stratotype and parastratotype sections. The investigated sections are located in southeastern France and northwestern Switzerland. The sections in southeast France are as follows: Broyon (Ardèche), Tithonian through early late Berriasian; Berrias (Ardèche), late Tithonian through early Valanginian; Lacisterne (Hérault), late Berriasian through early Valanginian; Ginestous-la Garenne (Hérault), late Berriasian through early Valanginian; Ginestous-les Oliviers (Hérault), latest Berriasian through basal Valanginian; Orpierre (HautesAlpes), latest Berriasian through early Hauterivian; La Charce (Drôme), late Valanginian through early late Hauterivian; Route d'Angles (Basses-Alpes), late Hauterivian; Sisteron (Basses-Alpes), late Hauterivian through early Aptian. Three sections from Switzerland were investigated. They are as follows: Valangin, latest Berriasian through early late Hauterivian; Hauterive, Hauterivian; Le Landeron, late early Hauterivian through late Hauterivian. All are in the Jura Mountains. Detailed geographic, lithologic, and biostratigraphic information on these sections is presented by Thierstein (1973), who sampled the French and Swiss sections for the Chevron Oil Field Research Company. The Neocomian stratotype zonation is based on the stratigraphic succession of species appearing at the base of the zone that it defines and names.

\section{Phoberocysta neocomica Zone}

Definition. Interval from the first appearance of Phoberocysta neocomica to the first appearance of $\mathrm{Bi}$ orbifera johnewingii.

Age. Basal Berriasian through the ammonite B. privasensis Subzone of the early late Berriasian.

Remarks. Muderongia simplex Alberti is a common constituent of this zone, although its first occurrence is in the late Kimmeridgian. Achomosphaera neptuni (Eisenack) and Cyclonephelium distinctum Deflandre and Cookson first appear in the middle part. Species that appear stratigraphically near the top (early late Berriasian) include Ctenidodinium elegantulum Millioud, Diacanthum hollisteri, Gonyaulacysta helicoidea (Eisenack and Cookson) Sarjeant, the tabulated Muderongia cf. M. simplex of Fisher and Riley (1980), Scriniodinium campanulum Gocht, and Tanyosphaeridium salpinx. Cometodinium whitei dominates some of the assemblages in this zone. P. neocomica, itself, is infrequent in the early parts of the zone and increases in frequency toward the top; cf. Prolixosphaeridium granulosum becomes stratigraphically persistent at the base.

Distribution. Present in southeast France (section at Berrias), the Phoberocysta neocomica Zone has thus far not been identified in sections studied from the North Atlantic, presumably because of the poorly palyniferous interval directly below the $B$. johnewingii Zone (Habib, 1978). Williams (1975) and Bujak and Williams (1978) used a zone defined by $P$. neocomica to date the oldest Neocomian in wells drilled offshore southeastern Canada. Davey (1979) placed the lowest occurrence of this species in the latest Berriasian, perhaps because of the absence of the lower part of the Berriasian in the Speeton Clay of England.

\section{Biorbifera johnewingii Zone}

Definition. Interval from the first appearance of Biorbifera johnewingii to the first appearance of Druggidium apicopaucicum.

Age. Early late Berriasian (ammonite $D$. dalmasi Subzone) to the top of the Berriasian.

Remarks. Species that have their first occurrence at the base of this zone include Hystrichodinium pulchrum Deflandre sensu stricto and Kleithriaspheridium fasciatum Davey. Species commencing slightly above the base include Heslertonia heslertonensis (Neale and Sarjeant), Oligosphaeridium complex (White), and Polysphaeridium warrenii Habib. There are several taxa that commence in the uppermost part of this zone. Notable among these are Aprobolocysta varigranosa Duxbury, Batioladinium gochtii (Alberti), and Pseudoceratium pelliferum Gocht. Amphorula metaelliptica is restricted to the Biorbifera johnewingii Zone. Cometodinium whitei is a common constituent in many samples.

Distribution. In southeast France $B$. johnewingii is present in the Berriasian of three of the sections studied (Lacisterne, Ginestous-la Garenne, Orpierre). It is also 


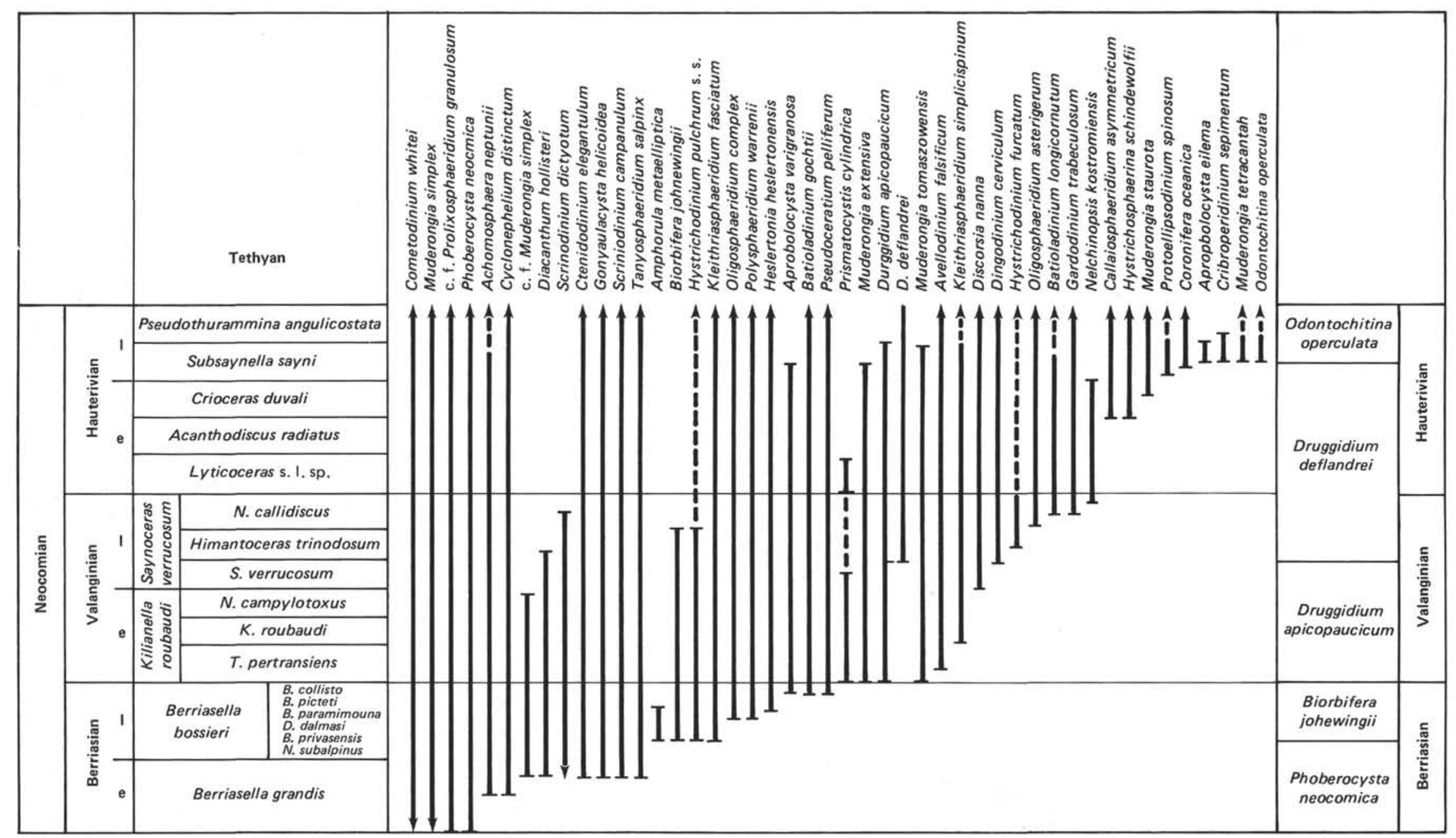

Figure 3. Ammonite-dated dinoflagellate stratigraphy and zonation of Neocomian stratotype and parastratotype sections. 
present in the Berriasian of the Speeton Clay in England, although as a rare constituent. B. johnewingii is widespread in offshore southeastern Canada, and in the North Atlantic. It also occurs in the Neocomian of the Sacramento Valley sequence of California (Habib and Warren, 1973).

\section{Druggidium apicopaucicum Zone}

Definition. Interval from the first appearance of Druggidium apicopaucicum to the phylogenetic appearance of $D$. deflandrei.

Age. Earliest Valanginian (basal T. pertransiens Zone) through early late Valanginian (Saynoceras verrucosum Zone).

Remarks. Prismatocystis cylindrica Habib, Muderongia extensiva Duxbury, and M. tomaszowensis Alberti appear at the base of this zone. Avellodinium falsificum Duxbury starts just above the base of this zone and Kleithriasphaeridium simplicispinum (Davey and Williams) has its first appearance near the base. Discorsia nanna (Davey) first appears near the top.

Distribution. In southeastern France Druggidium apicopaucicum is present within this zone in the Orpierre and La Charce sections. The D. apicopaucicum Zone is widely distributed in the North Atlantic, near both the eastern and western margins. The nominative species occurs rarely elsewhere in western Europe (e.g., basal Valanginian of the Speeton Clay) or is absent.

\section{Druggidium deflandrei Zone}

Definition. Interval from the first appearance of $D$. deflandrei to the first appearance of Odontochitina operculata.

Age. Late Valanginian (Himantoceras trinodosum Zone) to late Hauterivian (almost to the top of the Subsaynella sayni Zone).

Remarks. A species making its first appearance at the base of this zone is Dingodinium cerviculum. Species appearing in the lower part of this zone include $H y$ strichodinium furcatum Alberti, Oligosphaeridium asterigerum (Gocht), Batioladinium longicornutum (Alberti), Gardodinium trabeculosum (Gocht) Alberti sensu stricto, and Nelchinopsis kostromiensis (Vozzhennikova). Species occurring near the top of this zone include Callaiosphaeridium asymmetricum (Deflandre and Courteville) sensu stricto, Hystrichosphaerina schindewolfii Alberti, Muderongia staurota Sarjeant, Protoellipsodinium spinosum Davey and Verdier, and Coronifera oceanica Cookson and Eisenack. Species becoming extinct in the basal part of this zone include Biorbifera johnewingii, Diacanthum hollisteri, and Scriniodinium dictyotum.

Distribution. The nominative species is present in the sections at Orpierre, La Charce, Route d'Angles, and Sisteron in southeast France. It is also present as a rare element in the Hauterivian of the Speeton Clay in England. This zone is equivalent in age to the combined Druggidium deflandrei-D. rhabdoreticulatum Zones of the North Atlantic (Fig. 2). In the western North Atlantic B. johnewingii, Diacanthum hollisteri and S. dictyo- tum also disappear stratigraphically in the lower part of the Druggidium deflandrei Zone.

\section{Odontochitina operculata Zone}

Definition. The lower boundary is defined by the first appearance of Odontochitina operculata. The top of the zone is undefined because the stratotype study does not extend beyond latest Hauterivian.

Age. Late Hauterivian (near the top of the Subsaynella sayni Zone) at the base.

Remarks. Aprobolocysta eilema Duxbury, Cribroperidinium sepimentum Neale and Sarjeant, and $\mathrm{Mu}$ derongia tetracantha (Gocht) have their lowest occurrence at the base of this zone in the investigated type section. Druggidium apicopaucicum becomes extinct in the same interval.

Distribution. $O$. operculata is present in sections at Route d'Angles and Sisteron in southeast France; and it first occurs in the $S$. gottschei Zone of the Speeton Clay of England. The stratigraphic level is the same as the first occurrence in southeast France. O. operculata is a cosmopolitan species that has been reported as appearing at this approximate level in widely separated areas. Davey (1979) defined an Odontochitina operculata Zone as beginning at the Hauterivian/Barremian boundary in the Speeton Clay.

The North Atlantic zonation (Habib, 1977) was dated originally from the section recovered at Site 105, through comparison with Thierstein's nannofossil study (1975) of the Berriasian-Hauterivian interval in that section and with Luterbacher's report (1972) of Albian planktonic foraminifers. Subsequent study of the section from Hole 391C (Habib, 1978) yielded zonal fossils (e.g. Phoberocysta neocomica), which permitted comparison with stratotype Neocomian-Aptian sections published by Millioud (1969).

Our investigation of Neocomian stratotype and ammonite-dated parastratotype sections shows that most of the species used to zone and date the North Atlantic occur in both areas, and provides evidence of precise age determinations where it was previously lacking. For example, at both Site 105 and Hole 391C the lower boundary of the Biorbifera johnewingii Zone was dated as undifferentiated Berriasian because of the paucity of dinoflagellates in the interval directly above the Cretaceous/Jurassic boundary dated by Thierstein (1975). In the European sections, $B$. johnewingii appears very close to the boundary between the early and late Berriasian. We use this evidence to date the first occurrence of this species in the North Atlantic as early late Berriasian. Support for this conclusion is drawn from Site 387 nannofossil data (Okada and Thierstein, 1979), which date the interval containing the first appearance of $B$. johnewingii as late Berriasian.

Species of Druggidium, for example, D. apicopaucicum Habib and D. deflandrei (Millioud), also occur in both areas of study and in corresponding chronostratigraphic order. The base of the Druggidium apicopaucicum Zone was dated early Valanginian in the North Atlantic, which is in general agreement with the earliest 
Valanginian appearance of this species in the stratotype area. Also, in both areas $D$. deflandrei appears in assemblages dated late Valanginian.

The Druggidium rhabdoreticulatum Zone is widespread in the western North Atlantic, although its age is uncertain (Hauterivian or Barremian, according to $\mathrm{Ha}-$ bib, 1977) because of its absence in the investigated stratotype sections. However, Davey (1979) reported the first appearance of $D$. rhabdoreticulatum in the Speeton Clay of England in Hauterivian assemblages, and in the same stratigraphic order beneath the first appearance of Odontochitina operculata. The Druggidium rhabdoreticulatum Zone is retained for the North Atlantic because of its value in correlation; it occurs at such widely separated localities as those of Sites 105, 387, and Hole 391C (Fig. 1). It is assigned to the Hauterivian.

In the stratotype sections, $O$. operculata appears stratigraphically in sediments of the late Hauterivian (Fig. 3 ), which allows a more precise age determination for the base of the zone defined by this species than the Hauterivian or Barremian originally proposed by Habib (1977). On the basis of the stratigraphy of Hole 391C, two subzones were distinguished in the Odontochitina operculata Zone: the lower Phoberocysta neocomica Subzone and the higher Subtilisphaera perlucida Subzone. Habib (1978) defined the lower subzone as the interval from the first appearance of $O$. operculata to the last appearance of $P$. neocomica. This subzone is now renamed the Odontochitina operculata Zone (sensu stricto), as the name originally given (Odontochitina operculata Zone sensu Habib, 1977) is abandoned.

Less information is available for comparing the Aptian-Cenomanian zonation in the North Atlantic with European stratotype sections. Davey and Verdier (1971; 1974) described the dinoflagellate stratigraphy of the type Albian and Aptian stages, but it contains relatively few species in common with the North Atlantic. In the North Atlantic, the Subtilisphaera perlucida Zone is considered to range from Aptian to early Albian in the stratigraphic interval containing $S$. perlucida from immediately above the last occurrence of $P$. neocomica to the first appearance of Spinidinium vestitum Brideaux. Subtilisphaera perlucida occurs in both the La Bédoule and Gargas Aptian stratotype sections studied by Davey and Verdier (1974), along with Dingodinium cerviculum Cookson and Eisenack. In Hole 391C, D. cerviculum and Druggidium deflandrei range into the Subtilisphaera perlucida Zone. The stratigraphic disappearance of Dingodinium cerviculum and Druggidium deflandrei is considered useful for dating sediments close to the Aptian/Albian boundary in the North Atlantic, because both occur in intervals independently dated Aptian at several North Atlantic sites. For example, Dingodinium cerviculum and Druggidium deflandrei occur (Habib, 1972 ) in the eastern North Atlantic in an interval that calcareous nannofossil evidence indicates ranges from early to late Aptian (Roth and Thierstein, 1972; see also Thierstein, 1973, fig. 23). In the stratotype stratigraphy, D. deflandrei last appears in the late Aptian at Gargas and Dingodinium cerviculum last appears in few specimens in the earliest Albian.
The Spinidinium vestitum Zone ranges from middle Albian or late early Albian to Vraconian Albian, in the stratigraphic interval defined by Habib (1977) from the first appearance of the nominative species to the phylogenetic appearance of Spindinium echinoideum. The precise age of the lower boundary of this zone is unknown; planktonic foraminiferal evidence at Site 105 (J. Sigal, personal communication, 1981) indicates the middle or late early Albian. The upper boundary lies within the Vraconian Albian, on the basis of foraminiferal evidence at Site 105 and Hole 101A (Luterbacker, 1972).

The Spinidinium echinoideum and Trithyrodinium suspectum Zones of Habib (1977) range collectively from Vraconian Albian through the Cenomanian. The boundary between the two zones was defined at Site 105 by the first appearance of $T$. suspectum in the middle Cenomanian. At Site 137 (Habib, 1972), T. suspectum first appears in a relatively thick section dated Cenomanian.

\section{AGE OF LITHOSTRATIGRAPHIC UNITS}

Based on the ages provided from the dinoflagellate stratigraphy, the lowermost, unnamed lithostratigraphic unit (Section 534A-127-2 to Sample 534A-111-1, 7 $\mathrm{cm}$ ) ranges from middle Callovian to basal Kimmeridgian. The middle Callovian/late Callovian boundary is placed between Samples 534A-124-1, 54-56 cm and 534A-124-1, 8-10 cm, on the basis of the last appearance of Ctenidodinium gochtii in the former sample. The Callovian/Oxfordian boundary lies in the dark green radiolarian claystones, between Samples 534A$122-2,68-70 \mathrm{~cm}$ and $534 \mathrm{~A}-121-1,46-48 \mathrm{~cm}$. The boundary is defined by the first appearance of Polygonifera evittii in the latter sample. The Oxfordian/Kimmeridgian boundary lies very near the top of this unit, between Samples 534A-112-1, 69-71 cm and 534A-111-1, 27-29 $\mathrm{cm}$. It is defined by the first appearance of Occisucysta balia in the latter sample, approximately $20 \mathrm{~cm}$ below the lithologic boundary.

The lower green-gray interbedded calcareous claystone and limestone lithology of the Cat Gap Formation (Samples 534A-111-1, $7 \mathrm{~cm}$ to 534A-103-1, $107 \mathrm{~cm}$ ) is almost entirely Kimmeridgian. The Kimmeridgian/Tithonian boundary is placed very near the top of this unit, between Samples 534A-105-1, 17-18 cm and 534A-104-2, $59-61 \mathrm{~cm}$. The Tithonian age of the latter sample is recognized by the occurrence of Cometodinium whitei. The base of this facies is earliest Kimmeridgian. Previously, the oldest lithology of the Cat Gap Formation was cored at Site 100 (Hollister et al., 1972). It was considered to be Oxfordian or Callovian, because of the evidence provided by dinoflagellates (Habib, 1972; Jansa, et al., 1979). However, restudy of the lowermost sediment at this site (Core 100-10) reveals the presence of Dinopterygium dimorphum, Occisucysta evittii, and $O$. balia, which indicates an age not older than Kimmeridgian. This assemblage also contains the pentagonal morphotype of Sirmiodinium grossii.

The upper grayish red calcareous claystone lithology (Samples 534A-103-1, $107 \mathrm{~cm}$ to 534A-92-2, $40 \mathrm{~cm}$ ) of the Cat Gap Formation is Tithonian. In Hole 534A, the 

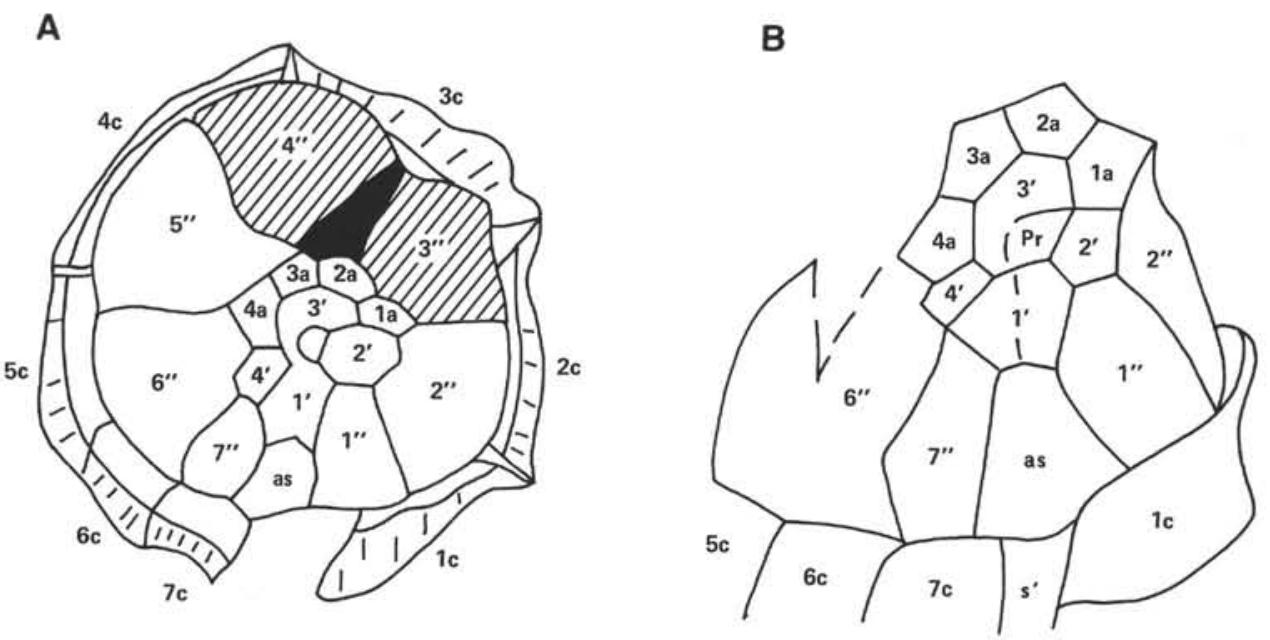

Figure 4. Druggidium apicopaucicum Habib presented in a schematic, Kofoid-style tabulation of the micrographs illustrated in Plate 3. A. Plate 3, Figure 3-tabulation of epicyst and cingulum. (Attached opercular pieces are indicated by diagonal pattern.) B. Plate 3, Figures 1 and 2 -enlarged view of preapical, apical, and anterior intercalary cluster of plates. (Dashed line vertically bisecting the first apical plate indicates that in some specimens it is subdivided into two plates. Nearly square sixth and seventh plates of the cingulum are diagnostic of the genus.) (See Taxonomic Note section for an explanation of symbols.)

Tithonian is represented by a thicker section than that indicated by calcareous nannofossils (Site 534 report, this volume), because of the stratigraphically lower position of the Kimmeridgian/Tithonian boundary defined by dinoflagellates. The stratigraphic disparity of this boundary is evident at Site 105 as well. Thierstein (1976) placed the Kimmeridgian/Tithonian boundary between Cores 105-34 and 105-35, based on the nannofossil evidence. Although the dinoflagellate stratigraphy of the Jurassic at Site 105 has not yet been restudied, Habib (1976) indicated that $C$. whitei ranges down to Sample 105-35,CC. This indicates that the Kimmeridgian/Tithonian boundary at Site 105 is approximately 9 $\mathrm{m}$ lower (e.g., between Cores 105-35 and 105-36) than that indicated by the nannofossils.

At Hole 534A the age of the Blake-Bahama Formation ranges from Tithonian at the base, close to the Jurassic/Cretaceous boundary, to early Bedoulian Aptian, at the top of the turbiditic beds. The Jurassic/Cretaceous boundary is placed between Samples 534A-91-3, $40-41 \mathrm{~cm}$ and $534 \mathrm{~A}-91-2,57-58 \mathrm{~cm}$, based on the first stratigraphically persistent appearance of Prolixosphaeridium $\mathrm{sp}$. in the latter sample. This boundary is approximately $10 \mathrm{~m}$ higher than the boundary between the Blake-Bahama Formation and the underlying Cat Gap Formation. The age of the upper boundary is based on the last appearance of Phoberocysta neocomica in Sample $534 \mathrm{~A}-49-4,30-32 \mathrm{~cm}$. The turbiditic interval of Cores 534A-64 to 534A-49 ranges from the Hauterivian to early Bedoulian.

The Hatteras Formation ranges from early Bedoulian Aptian to Vraconian Albian. The interbedded transitional lithologies of Cores $534 \mathrm{~A}-48$ to $534 \mathrm{~A}-43$ are Aptian, as they are within the interval from the last appearance of $P$. neocomica to the last appearance of Druggidium deflandrei. The variegated claystone inter$\mathrm{val}$ of Cores $534 \mathrm{~A}-42$ to $534 \mathrm{~A}-40$ is largely barren of pa- lynomorphs. However, the occurrence of $D$. deflandrei in Sample 534A-41-6, 42-44 cm indicates that this stratigraphic level is not younger than the late Aptian. The carbonaceous clay lithology of Cores 534A-39 to 534A32 is of early Albian to late Albian. The interval of Cores $534 \mathrm{~A}-30$ to $534 \mathrm{~A}-27$ is Vraconian Albian.

\section{TAXONOMIC NOTE}

Based on the scanning electron microscopy of type material in Sample 105-24-1, 100-102 cm at Site 105 (Habib, 1973), the type species of Druggidium, D. apicopaucicum is shown (Plate 3; Fig. 4) to have the cyst tabulation formula $\operatorname{Pr} .4^{\prime}, 4 a, 7^{\prime \prime}, 7 \mathrm{c}, 6^{\prime \prime \prime}, \mathrm{lp}, 1^{\prime \prime \prime \prime}$, $\mathrm{s}+$ as, and the archeopyle formula $2 \mathrm{P}_{3^{\prime \prime}-4^{\prime \prime}}$. The hypocystal tabulation and the tabulation of the cingulum remain the same as originally described by Habib (1973). However, the epicystal tabulation is revised, based mainly on micrographs of the small cluster of plates near the apex.

The pre-apical plate is subcircular and contains a small plug at its center. The apical series consists of four plates, of which the fourth is smallest and most slender. The third apical plate is located dorsal of the pre-apical plate. The anterior intercalary series consists of four trapezoidal plates, all of which at least partially contact the third apical plate. The precingular series consists of seven plates. The first and seventh precingular plates lie on either side of the anterior sulcal plate and are the most slender in the series. The archeopyle forms from the opening of the third and fourth precingular plates. The opercular pieces remain attached on the cyst in D. apicopaucicum, along the cingulum.

\section{ACKNOWLEDGMENTS}

R. J. Davey (Shell U. K. Exploration and Production Co., London) and H. L. Cousminer (U.S. Geological Survey, Washington) critically reviewed the manuscript. S. Hogg prepared the samples for study. M. Rafanelli typed the manuscript. C. Robertson and A. Jaroszewski prepared the diagrams.

We are grateful to Chevron Oil Field Research Company for providing time and facilities for this study. This study was supported by a grant from the National Science Foundation, OCE-7913191, at Queens College.

\section{REFERENCES}

Benson, W. E., Sheridan, R. E., et al., 1978. Init. Repts. DSDP, 44: Washington (U.S. Govt. Printing Office). 
Bernoulli, D., 1972. North Atlantic and Mediterranean Mesozoic facies: a comparison. In Hollister, C. D. Ewing, J. I., et al., Init. Init. Repts. DSDP, 11: Washington (U.S. Govt. Printing Office), 801-872.

Bujak, J. P., and Williams, G. L., 1978. Cretaceous palynostratigraphy of offshore southeastern Canada. Can. Geol. Surv. Bull., 297:1-19.

Davey, R. J., 1979. The stratigraphic distribution of dinocysts in the Portlandian (Latest Jurassic) to Barremian (Early Cretaceous) of northwest Europe. A.A.S.P. Contrib. Ser. No. 5B Contrib. Stratigraphic Palynology, 2:49-81.

Davey, R. J., and Verdier, J. P., 1971. An investigation of microplankton assemblages from the Albian of the Paris Basin. Verh. K. Ned. Akad. Wet., 26(2):1-58.

1974. Dinoflagellates cysts from the Aptian type sections at Gargas and La Bédoule, France. Palaeontology, 17(3):623-653.

DeRenéville, P., and Raynaud, J. F., 1981. Palynologie du stratotype du Barrémien. Bull. Cent. Rech. Explor. Prod. Elf-Aquitaine, 5 (1):1-29.

Dörhöfer, G. G., 1979. Distribution and stratigraphic utility of Oxfordian to Valanginian miospores in Europe and North America. A.A.S.P. Contrib. Ser. No. 5B Contrib. Stratigraphic Palynology, 2:101-132.

Fensome, R. A., 1979. Dinoflagellate cysts and acritarchs from the Middle and Upper Jurassic of Jameson Land, East Greenland. Grфnl. Geol. Unders. Bull. 132:1-98.

Fisher, M. J., and Riley, L. A., 1980. The stratigraphic distribution of dinoflagellate cysts at the Boreal Jurassic-Cretaceous boundary. Fourth Init. Palynol. Conf., Lucknow, 2:313-329.

Habib, D., 1972. Dinoflagellates and other palynomorphs in selected samples from Leg 14 Deep Sea Drilling Project. In Hayes, D. E., Pimm, A. C., et al., Init. Repts. DSDP, 14: Washington (U.S. Govt. Printing Office), 649-654.

1973. Taxonomy, morphology, and suggested phylogeny of the dinoflagellate genus Druggidium. Geosci. and Man, 7:47-55.

1976. Neocomian dinoflagellate zonation in the western North Atlantic. Micropaleontology, 21(4):373-392.

1977. Comparison of Lower and Middle Cretaceous palynostratigraphic zonations in the western North Atlantic. In Swain, F. M., (Ed.), Stratigraphic Micropaleontology of Atlantic Basin and Borderlands: New York (Elsevier), pp. 341-367.

1978. Palynostratigraphy of the Lower Cretaceous section at Deep Sea Drilling Project Site 391, Blake-Bahama Basin, and its correlation in the North Atlantic. In Benson, W. E., Sheridan, R. E., et al., Init. Repts. DSDP, 44: Washington (U.S. Govt. Printing Office), 887-897.

Habib, D., and Warren, J. S., 1973. Dinoflagellates near the Cretaceous-Jurassic boundary. Nature, 241(5386):217-218.

Hollister, C. D., Ewing, J. I., et al., 1972. Init. Repts. DSDP, 11: Washington (U.S. Govt. Printing Office).

Ioannides, N. S., Stavrinos, G. N., and Downie, C., 1977. Kimmeridgian microplankton from Clavell's Hard, Dorset, England. Micropaleontology, 22(4):443-478.
Jansa, L. F., Enos, P., Tucholke, B. E., Gradstein, F. M., and Sheridan, R. E., 1979. Mesozoic-Cenozoic sedimentary formations of the North American Basin; western North Atlantic. In Talwani, M., Hay, W., and Ryan, W. B. F., Deep Drilling Results in the Atlantic Ocean: Continental Margins and Paleoenvironment. Am. Geophys. Union, Maurice Ewing Ser., 3:1-57.

Klement, K. W., 1960. Dinoflagellaten und hystrichosphaerideen aus dem unteren und mittleren Malm, Sudwestdeutschlands. Palaeontographica A, 114:1-104.

Lentin, J. K., and Williams, G. L., 1976. A monograph of fossil peridinoid dinoflagellate cysts. Bedford Inst. Oceanography Rep. BI$R-75-16$, pp. $1-237$.

Luterbacher, H. P., 1972. Foraminifera from the Lower Cretaceous and Upper Jurassic of the northwestern Atlantic. In Hollister, C. D., Ewing, J. I., et al., Init. Repts. DSDP, 11: Washington (U.S. Govt. Printing Office), 561-593.

Millioud, M. E., 1969. Dinoflagellates and acritarchs from some western European Lower Cretaceous type localities. Proc. Int. Conf. Planktonic Microfossils, Geneva, 1967, 2:420-434.

Okada, H., and Thierstein, H. R., 1979. Calcareous nannoplankton, Leg 43, Deep Sea Drilling Project. In Tucholke, B. E., Vogt, P. E., et al., Init. Repts. DSDP, 43: Washington (U.S. Govt. Printing Office), 507-574.

Pocock, S. A. J., 1972. Palynology of the Jurassic sediments of western Canada. Part 2, marine species. Palaeontographica B, 137: 85-153.

Raynaud, J. F., 1978. Principaux dinoflagellés caractéristiques du Jurassique Superiéur d'Europe du Nord. Palinologia, 1:387-405.

Reyre, Y., 1973. Palynologie du Mesozoique saharien. Mem. Mus. Nat. Hist. Nat., 27:1-284.

Roth, P. H., and Thierstein, H., 1972. Calcareous nannoplankton: Leg 14 of the Deep Sea Drilling Project. In Hayes, D. E., Pimm. A. C., et al., Init. Repts. DSDP, 14: Washington (U.S. Govt. Prịnting Office), 421-486.

Stover, L. E., Sarjeant, W. A. S., and Drugg, W. S., 1977. The Jurassic dinoflagellate genus Stephanelytron: emendation and discussion. Micropaleontology, 23(3):330-338.

Sverdlove, M. S., and Habib, D., 1974. Stratigraphy and suggested phylogeny of Deflandrea vestita (Brideaux) comb. nov, and Deflandrea echinoidea Cookson and Eisenack. Geosci. and Man, 9: 53-62.

Thierstein, H. R., 1975. Calcareous nannoplankton biostratigraphy at the Jurassic-Cretaceous boundary. Mem. Bur. Rech. Geol. Min. Fr., 86:84-94.

1973. Lower Cretaceous calcareous nannoplankton biostratigraphy. Abh. Geol. Bundesanst., 29:1-52.

1976. Mesozoic calcareous nannoplankton biostratigraphy of marine sediments. Mar. Micropaleontol., 1:325-362.

Williams, G. L., 1975. Dinoflagellate and spore stratigraphy of the Mesozoic-Cenozoic, offshore eastern Canada. Geol. Surv. Can. Pap., 74-30(2):107-161. 

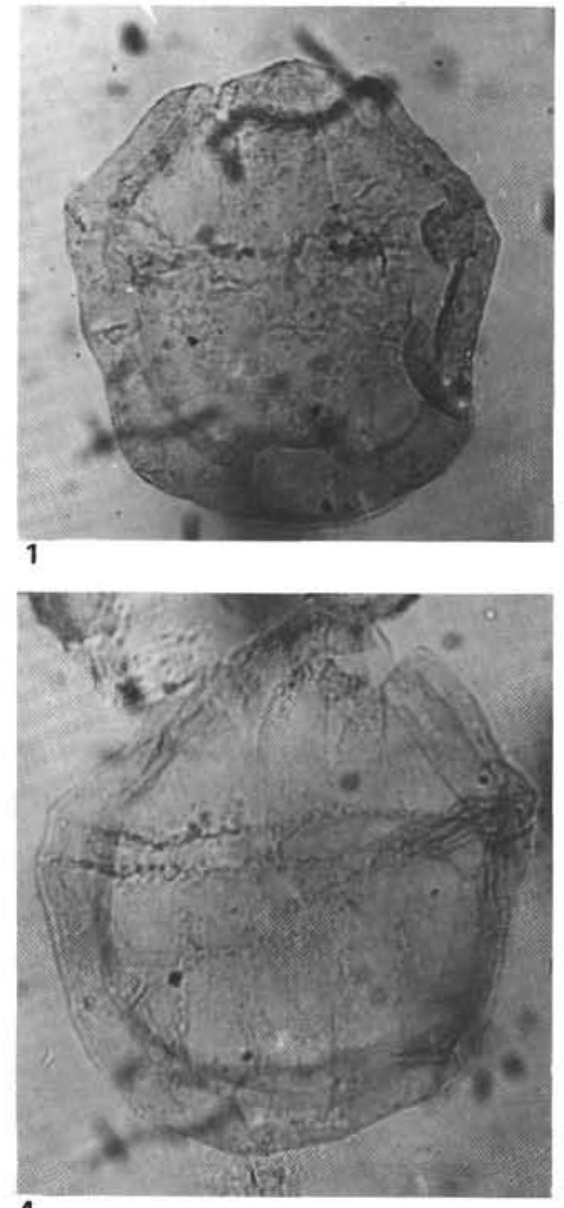

4

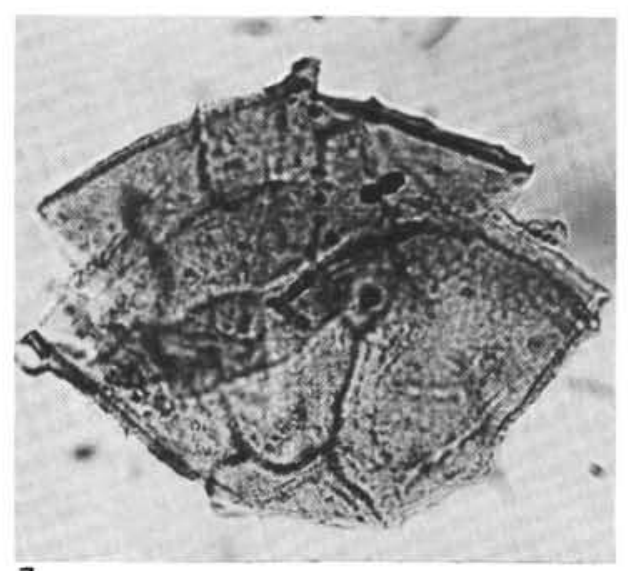

7

2

5
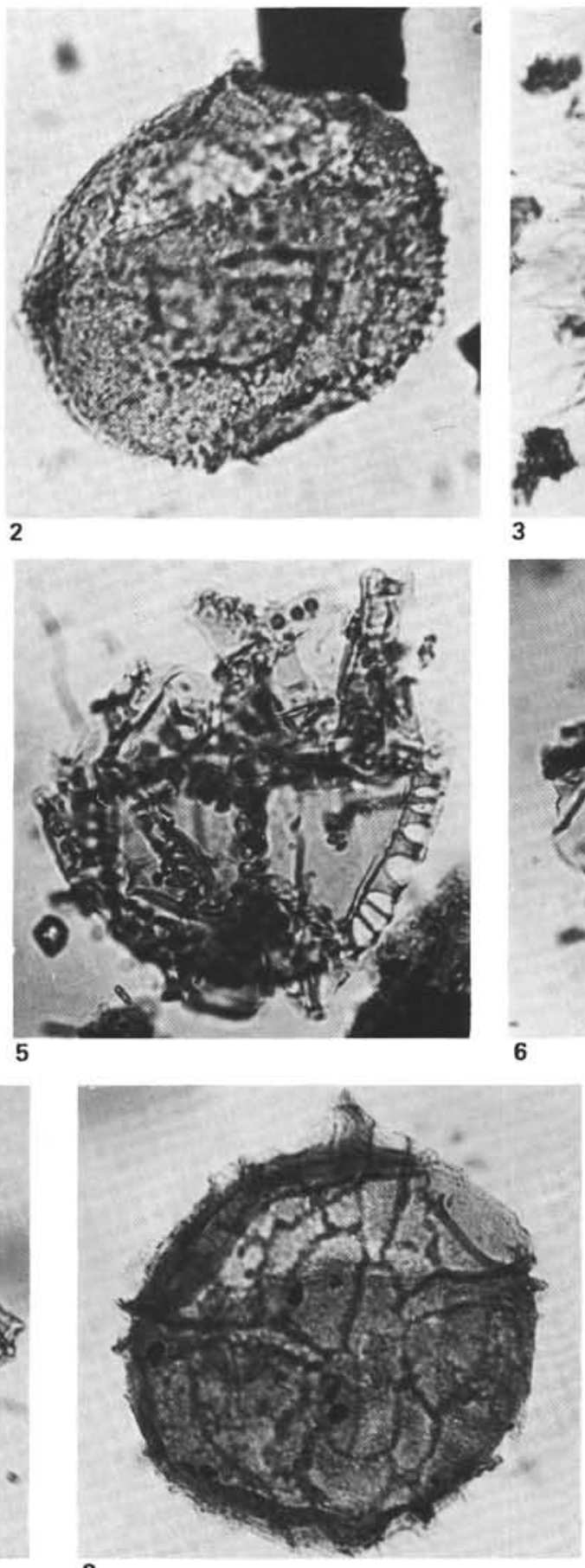

8

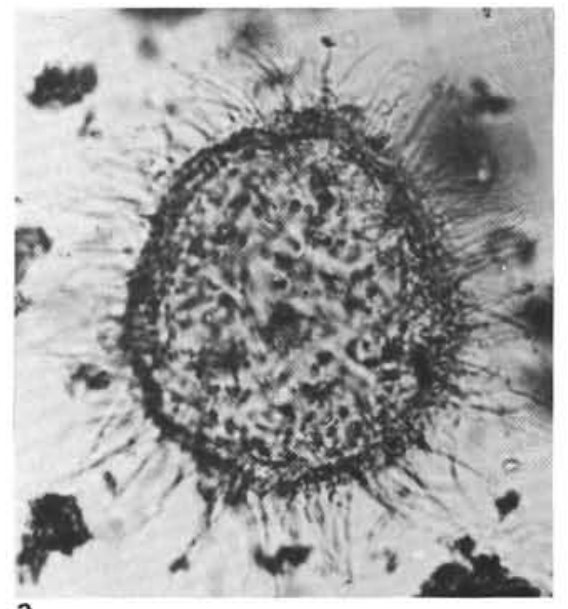

3

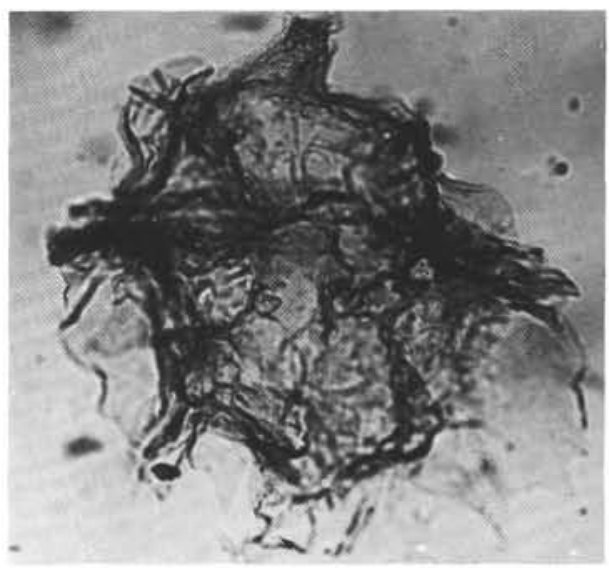

6

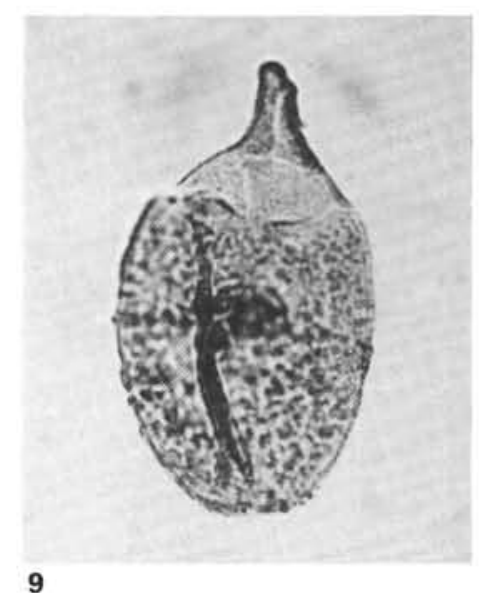

Plate 1. Dinoflagellate species with diagnostic datums in the Jurassic (magnifications not to scale; dimensions of each specimen specified in micrometers). 1, 4. Sirmiodinium grossii Alberti (pentagonal morphotype) (note perforation near antapex), (1) $90 \times 87 \mu \mathrm{m}$. Sample 534A-106-1, 3-4 cm. (4) $98 \times 90 \mu \mathrm{m}$. Sample 100-10-2, 145-147 cm at Site 100. 2. Occisucysta evittii (Dodekova). Note 2P archeopyle and lack of apical horn. $75 \times 78 \mu \mathrm{m}$. Sample 534A-104-2, 59-61 cm. 3. Cometodinium whitei (Deflandre and Courteville). $80 \times 75 \mu \mathrm{m}$. Sample 534A-84-7, 0-2 cm. 5. Stephanelytron redcliffense Sarjeant, emended Stover, Sarjeant, and Drugg. $55 \times 51 \mu \mathrm{m}$. Sample 534A-121-1, 8-10 $\mathrm{cm}$. 6. Dinopterygium dimorphum (Ioannides, Stavrinos, and Downie), $85 \times 86 \mu \mathrm{m}$. Sample 534A-106-1, 3-4 cm. 7. Ctenidodinium norrisii (Pocock). Note faint penetabular ridges within plate boundaries. $87 \times 109 \mu \mathrm{m}$. Sample 534A-124-1, 74-75 cm. 8. Occisucysta balia Gitmez. $67 \times 59 \mu \mathrm{m}$. Sample 534A-111-1, 27-29 cm. 9. Pareodinia evittii (Pocock). $52 \times 40 \mu \mathrm{m}$. Sample 534A-127-2, 34-35 cm. 


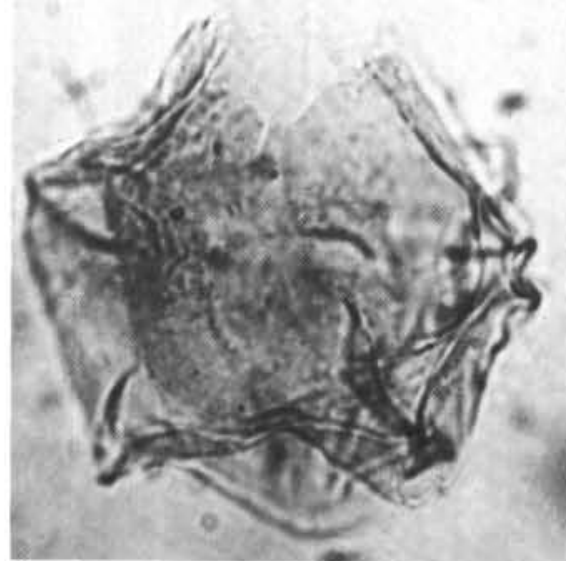

1

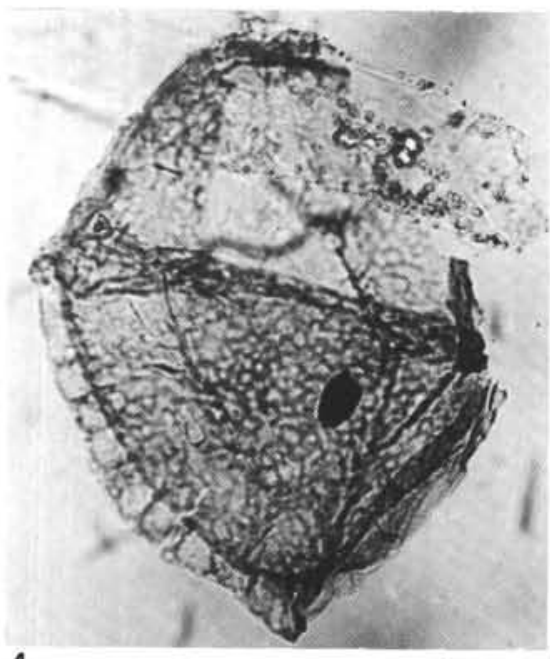

4

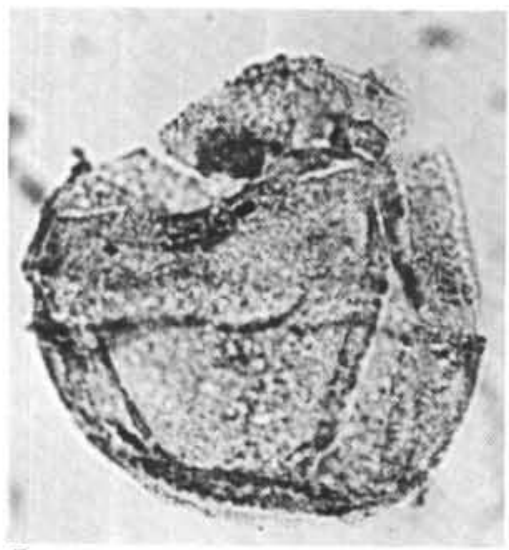

7

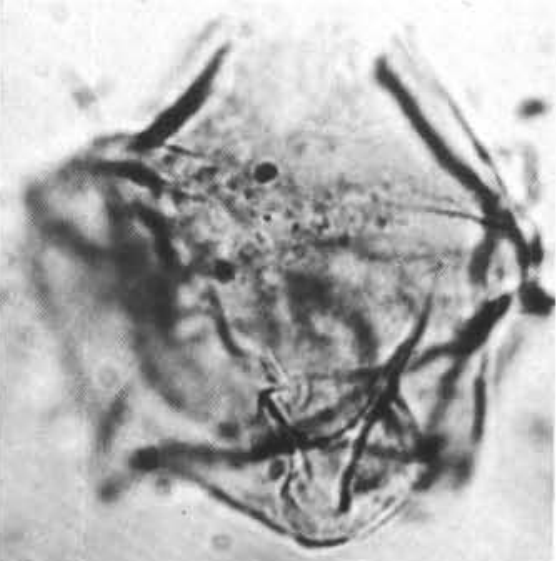

2

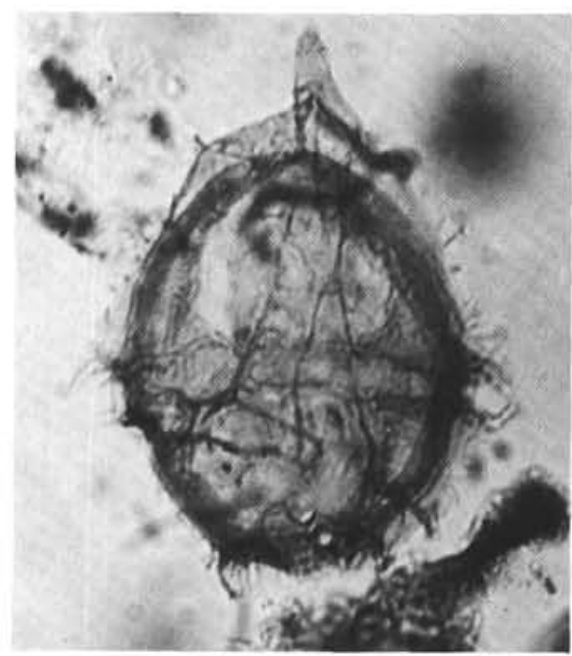

5

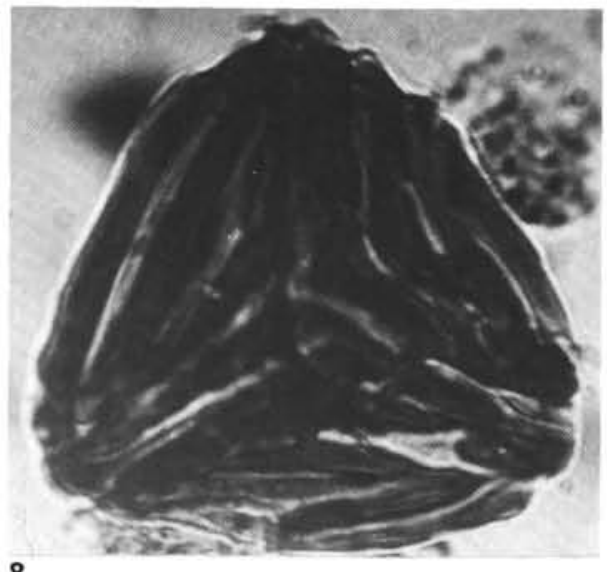

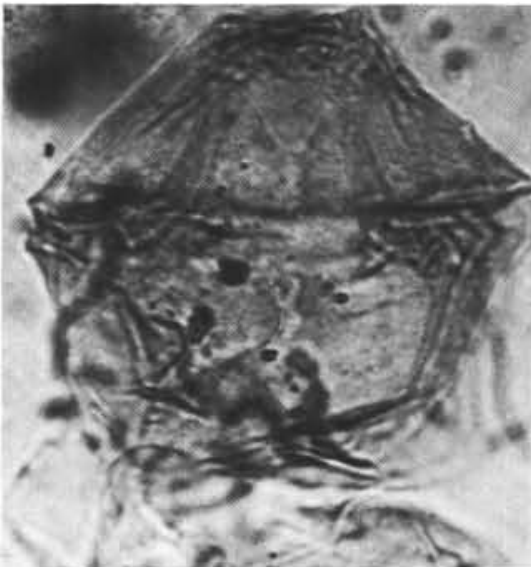

3

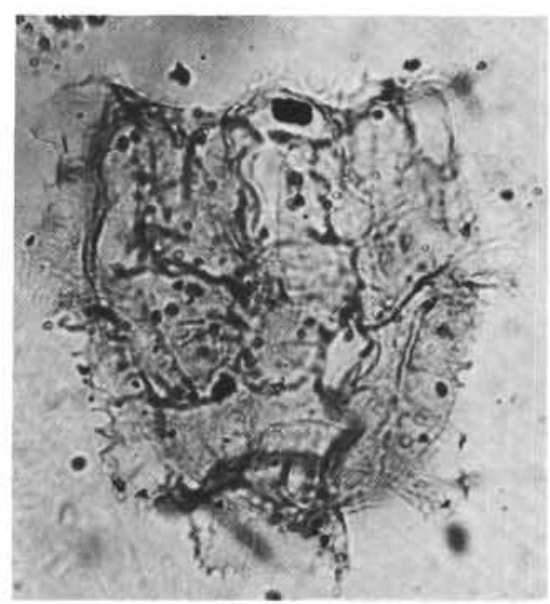

6

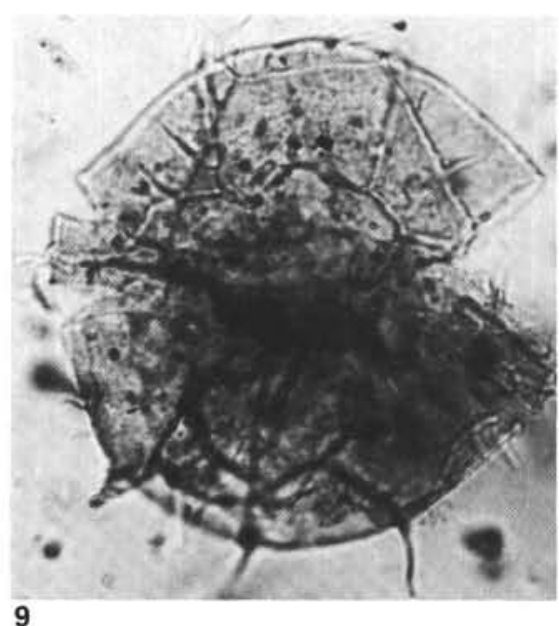

Plate 2. Dinoflagellate and spore species with diagnostic datums in the Jurassic (magnifications not to scale; dimensions of each specimen specified in micrometers). 1-3. Polygonifera evittii Habib. Specimens from paratype material in Sample 100-10-2, 145-147 cm at Site 100, (1) archeopyle margin reveals sulcal notch on ventral surface, ventral compression folds near antapical end of pericyst, $60 \times 62 \mu \mathrm{m}$, (2) same specimen, dorsal view (characteristic, long compression fold in dorsal hypocyst)., (3) specimen with single opercular piece (tA) in place (long first apical plate extends to sulcal region; apical horn is absent in this species; endocyst fills epicystal end of pericyst, leaving pericoels in the cingular and hypocystal areas [hypocavate]), $58 \times 62 \mu \mathrm{m}$. 4. Scriniodinium dictyotum Cookson and Eisenack. Reticulate ectophragm. $105 \times 63 \mu \mathrm{m}$. Sample $534 \mathrm{~A}-104-2,59-61 \mathrm{~cm}$. 5. Hystrichogonyaulax pectinigera (Gocht). Epicavate specimen with spinate plate boundaries. $55 \times 42 \mu \mathrm{m}$. Sample 534A-127-2, 34-35 cm. 6. Egmontodinium polyplacophorum Gitmez and Sarjeant. $75 \times 55 \mu \mathrm{m}$. Sample 534A-105-2, 92-94 cm. 7. Lithodinia sp. $55 \times 52 \mu \mathrm{m}$. Sample 534A-127-2, 34-35 cm. 8. Cicatricosisporites sp. Spore attributed to the schizaeaceous ferns. $75 \times 72 \mu \mathrm{m}$. Sample 534A-126-3, 13-17 cm. 9. Ctenidodinium ornatum (Eisenack). $85 \times 85 \mu \mathrm{m}$. Sample 534A-121-1, 8-10 cm. 


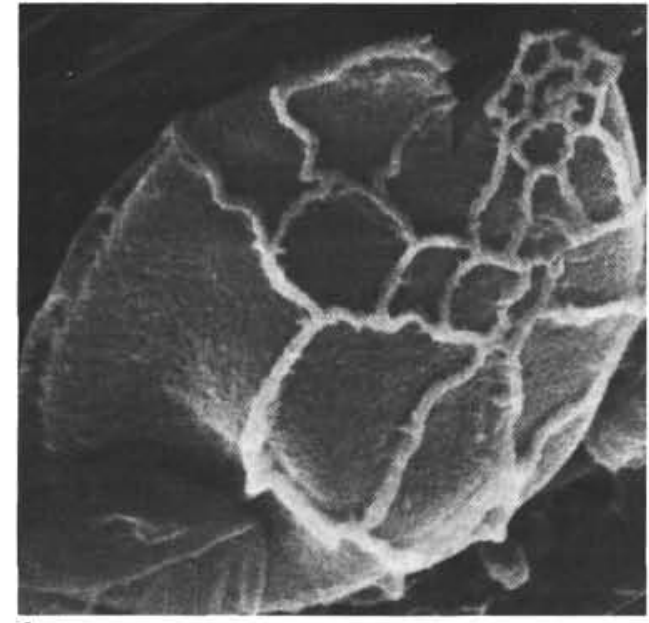

1

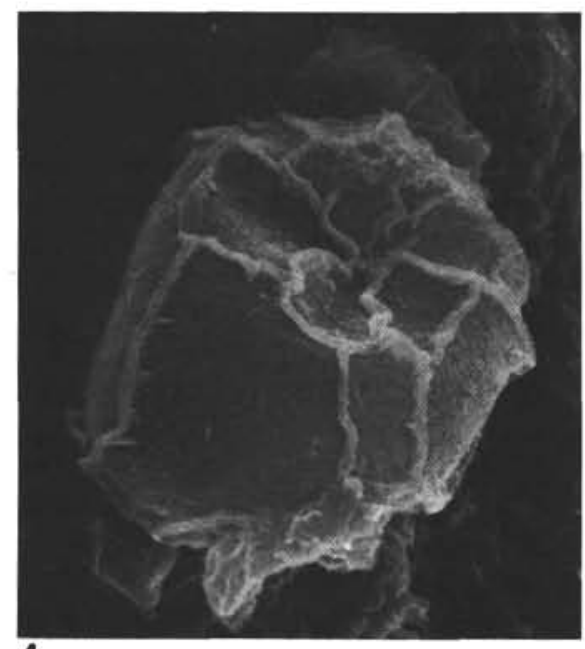

4

Plate 3. Druggidium apicopaucicum Habib. Scanning electron micrographs of specimens from paratype material in Sample 105-24-1, 100-102 cm at Site 105. 1-2. Tabulation of ventral surface, (1) $\times 2900$, (2) same specimen with enlarged view of epicystal plates, $\times 7000$ (Tabulation of this illustration is given in Fig. 4B in the text). 3. Apical view of epicyst (compare with Fig. 4A in the text). $\times 3000$. 4. Ventral surface. Large antapical plate tapers towards antapex, where it abuts the antapical margin of the slender fourth postcingular plate. $\times 2700$. Note the presence of the small acritarch Tabulimicrocystis tetragonis Habib and Knapp near the lower left-hand corner of the micrograph. 5. Dorsal view of species, showing slender fourth postcingular plate. Attached opercular pieces of $2 \mathrm{P}$ archeopyle evident. $\times 2700$. 6. Contact of antapical plate with third, fourth, and fifth postcingular plates. Note small, circular antapical perforation in this specimen. $\times 2700$. 